\title{
ANALISIS KELAYAKAN USAHA PETERNAKAN TRADISIONAL ITIK PETELUR DI KABUPATEN JEMBER
}

\author{
Hariadi Subagja ${ }^{1}$, Novi Pradita Erlina ${ }^{2}$, Erfan Kustiawan ${ }^{1}$ \\ 1Jurusan Perternakan, Politeknik Negeri Jember \\ 2Manajemen Bisnis Unggas, Politeknik Negeri Jember \\ Email: novipradita.e31@gmail.com
}

\begin{abstract}
INTISARI
Penelitian ini bertujuan untuk mengetahui seberapa besar pendapatan dan kelayakan usaha peternak itik petelur di Jember. Metode yang digunakan adalah survei dengan 36 responden peternak itik petelur. Hasil analisis kelayakan usaha diperoleh rata-rata B/C sebesar 1,87, BEP (harga) Rp983,27, BEP (produksi) sebesar 9.726,19 butir, dan ROI sebesar 55,70\%. Usaha itik petelur di beberapa kecamatan Kabupaten Jember menghasilkan pendapatan sebesar Rp656.408,00 (skala kurang dari 100 ekor), Rp2.346.371,00 (skala 100 sampai 500 ekor), dan Rp28.597.866,00 (skala lebih dari 500 ekor).
\end{abstract}

Kata kunci: Itik Petelur, Kelayakan Usaha, Pendapatan, Usaha Peternakan

\section{ABSTRACT}

This study aimed to determine how much income and business feasibility of duck laying farmers in Jember. The method used was a survey with 36 respondents duck laying farmers. The results of business feasibility analysis were B/C of 1.87, BEP (price) Rp983.27, BEP (production) 9,726.19 eggs, and ROI 55.70\%. The laying duck business in several districts of Jember had incomes Rp656,408.00 (scale less than 100 ducks), Rp2,346,371.00 (scale 100 to 500 ducks), and Rp28,597,866.00 (scale more than 500 ducks).

Keyword: Laying Ducks, Feasibility, Income, Poultry Business

\section{PENDAHULUAN}

\section{Latar Belakang}

Perkembangan usaha peternakan unggas di Indonesia relatif lebih maju bila dibandingkan dengan usaha peternakan lainnya. Berdasarkan data sensus pertanian 2013 jumlah usaha peternakan unggas yang meliputi ternak ayam lokal, ayam ras petelur, ayam ras pedaging, itik, dan itik manila adalah 7,77 juta unit (Badan Pusat Statistik, 2013).

Kontribusi peternakan unggas dalam menyumbang swasembada protein hewani terutama dalam pemenuhan kebutuhan makanan cukup tinggi. Peternakan unggas juga berperan sebagai sumber pendapatan, membuka kesempatan kerja, dan sebagai sumber protein hewani. Peternakan unggas menjadi usaha yang paling diminati karena selain pemeliharaan lebih mudah, perputaran investasi lebih cepat. Salah satu ternak unggas yang dipelihara oleh peternak yang ada di Indonesia adalah itik.

Populasi ternak itik semakin meningkat dari tahun ke tahun khususnya pada Kabupaten Jember. Kabupaten Jember merupakan salah satu kabupaten yang ada di Jawa Timur yang mempunyai total populasi ternak itik petelur sampai tahun 2014 
sebanyak 180 ribu ekor dengan jumlah produksi sebanyak 1,17 juta kg (Dinas Peternakan Jawa Timur, 2014). Jumlah itik yang banyak menandakan bahwa Kabupaten Jember merupakan salah satu daerah dengan potensi lingkungan yang baik untuk pemeliharaan itik.

Usaha peternakan itik bukan hanya sebagai usaha sampingan tetapi sudah memiliki orientasi bisnis yaitu sebagai usaha pokok. Usaha budidaya itik cukup dijadikan sebagai sumber pendapatan keluarga, sehingga dalam mengembangkan usaha ternak itik penting diketahui analisis kelayakan usaha itik petelur dengan kelompok skala usaha yang berbeda. Hal inilah yang melatarbelakangi untuk dilakukannya penelitian pada peternakan itik petelur di Kabupaten Jember. Penelitian telah dilaksanakan di Kecamatan Mumbulsari, Panti, Sukorambi, Silo, Sumbersari, Rambipuji, dan Ajung di Kabupaten Jember, Provinsi Jawa Timur. Ketujuh kecamatan tersebut mewakili 19,50\% dari total populasi itik di Kabupaten Jember (Dinas Peternakan dan Perikanan Kabupaten Jember, 2011). Studi tersebut diharapkan memberikan gambaran yang akurat mengenai kelayakan usaha pada masing-masing kelompok skala usaha itik di Kabupaten Jember, sehingga peternak dapat memilih skala usaha itik petelur yang terbaik untuk dilakukan guna memenuhi kebutuhan hidup.

\section{Tujuan Penelitian}

1. Untuk mengetahui tingkat penerimaan dan pendapatan peternak itik petelur di Kabupaten Jember.

2. Untuk mengetahui kelayakan usaha secara financial B/C, BEP, dan ROI peternak itik petelur di Kabupaten Jember.

\section{MATERI DAN METODE}

\section{Penentuan Lokasi}

Lokasi penelitian dilakukan dengan metode purposive sampling dengan pertimbangan bahwa lokasi penelitian dikenal sebagai sentra itik petelur di Kabupaten Jember. Lokasi penelitian dilakukan di tujuh kecamatan berbeda, yaitu: Kecamatan Mumbulsari, Kecamatan Panti, Kecamatan Sukorambi, Kecamatan Silo, Kecamatan Sumbersari, Kecamatan Rambipuji dan Kecamatan Ajung Kabupaten Jember.

\section{Pengumpulan Data}

Rancangan penelitian ini menggunakan rancangan penelitian survei yaitu penelitian dengan cara mengambil sampel dari satu populasi dan menggunakan kuesioner sebagai alat pengumpulan data. Data primer yang meliputi identitas responden, pengeleloan itik petelur, penerimaan usaha itik petelur, pengeluaran usaha itik petelur, dan jumlah investasi peternak yang digunakan dalam usaha itik petelur dari hasil observasi serta wawancara dengan peternak. Data sekunder berkaitan dengan usaha ternak itik petelur 
yang diperoleh dari observasi dan catatan pada instansi terkait.

Pemeliharaan itik terbagi menjadi tiga kelompok. Kelompok I peternak itik dengan populasi kurang dari 100 ekor, kelompok II peternak itik dengan populasi 100 sampai 500, dan kelompok III peternak dengan populasi lebih dari 500 ekor.

\section{Analisis Data}

\section{Penerimaan}

Penerimaan peternak itik petelur Kabupaten Jember dihitung menurut Soekartawi (2003).

Total Penerimaan $(\mathrm{TR})=\mathrm{Q} \times \mathrm{P}$

Keterangan:

$\mathrm{TR}=$ Total Revenue atau penerimaan $(\mathrm{Rp} / \mathrm{Bln})$

$\mathrm{Q}=$ Jumlah produksi

$\mathrm{P}$ = Harga (Rupiah)

\section{Pendapatan}

Pendapatan peternak itik petelur Kabuapten Jember dihitung menurut Soekartawi (2003).

Total Pendapatan $(\mathrm{Pd})=\mathrm{TR}-\mathrm{C}$

Keterangan:

$\mathrm{Pd}=$ Total pendapatan yang diperoleh peternak (Rp/Bln)

$\mathrm{TR}=$ Total Revenue atau penerimaan yang diperoleh peternak (Rp/Bln)

$\mathrm{TC}=$ Total Cost atau biaya yang dikeluarkan peternak (Rp/Bln)

\section{Kelayakan usaha}

Kelayakan usaha ternak itik petelur secara financial BEP, B/C (Benefit Cost Ratio), dan ROI (Return on Invesment).

B/C (Benefit Cost Ratio). B/C atau dikenal sebagai perbandingan atau nisbah antara tingkat keuntungan dan biaya.

$$
\mathrm{B} / \mathrm{C} \text { Ratio }=\frac{\text { Total Keuntungan }(\mathrm{Rp})}{\text { Total Biaya }(\mathrm{Rp})}
$$

BEP (Break Event Point). BEP adalah suatu kondisi yang menggambarkan bahwa hasil usaha tani yang diperoleh sama dengan modal yang dikeluarkan.

$$
\text { BEP produksi }=\frac{\text { Total Biaya Produksi }(\mathrm{Rp})}{\text { Harga Jual }(\mathrm{Rp} / \text { butir })}
$$

BEP harga. BEP harga menggambarkan harga terendah dari produk yang dihasilkan.

$$
\text { BEP harga }=\frac{\text { Total Biaya Produksi }(\mathrm{Rp})}{\text { Total Produksi (butir) }}
$$

ROI (Return on Invesment). Nilai ROI adalah analisis keuntungan usaha ternak itik petelur yang berkaitan dengan modal yang telah dikeluarkan.

$$
\text { ROI }=\frac{\text { Laba Usaha }}{\text { Modal }} \times 100 \%
$$

\section{HASIL DAN PEMBAHASAN}

Usaha itik petelur di beberapa kecamatan Kabupaten Jember memiliki prospek yang baik. Hasil analisis menunjukkan rata-rata nilai $\mathrm{B} / \mathrm{C} 1,87$, nilai $\mathrm{BEP}$ harga Rp923,27/butir, nilai BEP produksi 9.726,19 
butir dan ROI 55,70\%. Hasil perhitungan disajikan pada Tabel 1.

\section{Biaya Produksi}

Total biaya produksi peternak kelompok III jauh lebih tinggi dibandingkan peternak kelompok I dan II. Sesuai dengan pernyataan Nurana et al. (2004) semakin banyak biaya tetap dan biaya variabel yang dikeluarkan maka semakin banyak total biaya yang dihasilkan. Biaya produksi itik petelur pada peternak kelompok III paling tinggi dibandingkan kelompok lainnya, karena skalanya paling besar sehingga membutuhkan biaya yang lebih besar pula.

\section{Penerimaan}

Perbedaan penerimaan pada masingmasing kelompok peternak terjadi karena penerimaan yang diterima sangat dipengaruhi oleh jumlah produksi telur yang dihasilkan dan harga jual telur pada saat itu. Menurut Mongi (2014) penerimaan merupakan perkalian antara jumlah produksi yang dihasilkan dengan harga jual, maka semakin banyak produk yang dihasilkan maka akan semakin besar pula jumlah penerimaan yang diperoleh.

Penerimaan peternak itik petelur pada masing-masing kelompok sangat bervariasi. Kelompok dengan penerimaan tertinggi ialah kelompok III, dikarenakan jumlah telur dan harga jual paling tinggi dengan jumlah produksi telur sebesar 42.760 butir/bulan dan harga jual Rp1.600,00/butir, sedangkan kelompok I dan II memiliki jumlah produksi dan harga jual yang lebih rendah. Kelompok I jumlah produksi telur sebasar 1.327 butir/bulan dan harga jual Rp1.567,00/butir. Kelompok II jumlah produksi telur sebesar 5.047 butir/bulan dan harga jual Rp1.412,00/butir. Saediman (2012) menyatakan bahwa total penerimaan harus tinggi dibandingkan total biaya karena total penerimaan akan dikurangi dengan biaya total untuk memperoleh keuntungan, sehingga semakin tinggi selisih antara total penerimaan dengan total biaya maka semakin tinggi pula keuntungan yang diperoleh peternak.

$\underline{\text { Tabel 1. Hasil Analisis Usaha Itik Petelur di Kabupaten Jember/bulan }}$

\begin{tabular}{lcccc}
\hline Keterangan & Kelompok I & Kelompok II & \multicolumn{1}{c}{ Kelompok III } & Rata - Rata \\
\hline Total Biaya & $1.422 .036,00$ & $4.777 .840,00$ & $39.818 .134,00$ & $15.339 .337,00$ \\
Produksi (Rp) & $2.078 .444,00$ & $7.124 .211,00$ & $68.416 .000,00$ & $25.872 .855,00$ \\
$\begin{array}{l}\text { Penerimaan (Rp) } \\
\text { Pendapatan (Rp) }\end{array}$ & $656.408,00$ & $2.346 .371,00$ & $28.597 .866,00$ & $10.533 .548,00$ \\
$\begin{array}{l}\text { Kelayakan Usaha } \\
\text { 1. B/C }\end{array}$ & 2,17 & 2,40 & 1,39 & 1,87 \\
2. BEP Harga & $1.071,89$ & 946,73 & 931,20 & 923,27 \\
$\quad$ Rp) & & & & \\
3. BEP & $9.384,54$ & $24.886,33$ & $9.726,19$ \\
$\quad \begin{array}{l}\text { Produksi } \\
\text { (butir) }\end{array}$ & 907,68 & 49,11 & 71,82 & 55,70 \\
4. ROI & 46,16 & & & \\
\hline
\end{tabular}




\section{Pendapatan}

Kelompok dengan pendapatan tertinggi ialah peternak itik petelur kelompok III, karena pendapatan yang diperoleh lebih tinggi dibangdingkan kelompok lainnya. Besarnya pendapatan yang diperoleh menunjukkan tingkat keberhasilan usaha tersebut. Menurut Rasyaf (2002) bahwa besarnya pendapatan dari usaha ternak itik merupakan salah satu pengukur yang penting untuk mengetahui seberapa jauh usaha peternakan itik mencapai keberhasilan.

\section{Kelayakan Usaha}

Nilai rata-rata $\mathrm{B} / \mathrm{C}$ peternak itik di Kabupaten Jember sebesar 1,87 yang berarti bahwa pengeluaran biaya sebesar Rp15.339.337,00 akan menghasilkan penerimaan sebesar 1,87 kali lipat atau selama pemeliharaan diperoleh hasil $187 \%$ dari modal yang dikeluarkan.

Rata-rata BEP produksi peternakan itik petelur di Kabupaten Jember adalah 9.726,19 butir dan rata-rata BEP harga adalah Rp923,27. Ketiga kelompok peternak itik petelur tersebut layak untuk diusahakan karena semua rata-rata produksi telur dan harga telur yang berlaku saat itu berada di atas nilai BEP yang dimiliki masing-masing kelompok peternak. Kelompok III mempunyai nilai BEP harga dan nilai BEP produksi tertinggi, karena produksi dan harga telur yang berlaku memiliki selisih paling besar dengan nilai rata-rata BEP harga dan produksi. Menurut Sinaga, et al. (2013) suatu usaha dikatakan layak apabila nilai produksi rata- rata lebih besar dari BEP produksi dan nilai BEP harga lebih kecil dari harga jual telur itik rata-rata.

Kelompok peternak I, II, dan III mempunyai nilai ROI lebih tinggi dibandingkan dengan tingkat suku bunga yang berlaku dan selisih persentase antar kelompok peternak tidak terlalu besar. Kelompok III dibandingkan kelompok lainnya memiliki nilai rata-rata ROI yang paling tinggi sebesar $71,82 \%$, yang menunjukkan bahwa kelompok III mempunyai investasi modal yang dikeluarkan lebih efisien bila dibandingkan dengan investasi usaha peternak itik kelompok lainnya. Menurut Wulandari, et al. (2014) jika nilai ROI lebih besar dari tingkat bunga deposito, maka usaha ternak itik yang dijalankan mampu menghasilkan laba yang sesuai harapan peternak.

\section{KESIMPULAN DAN SARAN}

\section{Kesimpulan}

Pendapatan peternak itik petelur dibeberapa kecamatan Kabupaten Jember pada kelompok skala usaha kurang dari 100 ekor sebesar Rp656.408,00, skala 100 sampai 500 ekor sebesar Rp2.346.371,00, dan skala lebih dari 500 ekor sebesar Rp28.597.866. Seluruh peternak itik dinyatakan layak untuk dijadikan usaha pokok berdasarkan analisis kelayakan usaha dengan rata-rata B/C, BEP harga, BEP produksi dan ROI masing-masing sebesar 1,87, Rp923,27, 9.726,19 butir, 55,70. 


\section{Saran}

Penelitian lebih lanjut diperlukan dengan menambah jumlah kecamatan yang diteliti agar lebih menggambarkan kelayakan usaha peternakan itik di Kabupaten Jember.

\section{DAFTAR PUSTAKA}

Anonimus. 2015a. Data produksi ternak Kab/Kota di Jawa Timur. http://disnak.jatimprov.go.id/web/laya nanpublik/datastatistik/ statistikproduksi. Diakses tanggal 7 April 2015.

Anonimus. 2015b. Data statistik populasi ternak Kab/Kota di Jawa Timur. http://disnak.jatimprov.go.id/web/ layananpublik/datastatistik/statistikpo pulasiternak. Diakses tanggal 7 April 2015.

Kamid, R. A. A. 2002. Analisis kelayakan usaha ternak itik petelur pada kelompok tani ternak itik branjangan putih Kecamatan Losari Kabupaten Cirebon. Skripsi. Fakultas Peternakan. Institut Pertanian Bogor. Bogor.

Mongi, H. 2014. Analisis profitabilitas usaha peternakan ayam petelur bina ternak mandiri di Kelurahan Mapane Kecamatan Poso Pesisir. Jurnal Agro Peternakan. 11(1).

Nurana, St. Rohani, dan K. Kasim. 2014. Analisis pendapatan peternak itik petelur sistem pemeliharaan nomaden di Desa Kaliang, Kecamatan Duampanua, Kabupaten Pinrang. Jurnal Ilmu dan Industri Peternakan. 1(3):263271.

Rasyaf, M. 2002. Beternak Itik. Edisi ke-16. Kanisius. Yogyakarta.

Saediman. 2012. Pengaruh skala usaha terhadap pendapatan peternak ayam ras petelur di Kecamatan Maritengngae Kabupaten Sidrap. Skripsi. Fakultas Peternakan. Universitas Hasanuddin. Makasar.

Sinaga, R., S.N. Lubis, dan H. Butar. 2013. Analisis usaha ternak itik petelur studi kasus Kecamatan Bandar Khalifah
Kabupaten Serdangbedagai. Journal on Social Economic of Agriculture and Agribusiness. 2(4).

Wulandari. S.P., B.A., Nugroho, dan H.D Utami. 2014. Analisis profitabilitas usaha peternakan itik petelur di Kecamatan Banyubiru Kabupaten Semarang. Skripsi. Fakultas Peternakan Universitas Brawijaya. Malang. 